International Research Journal of Management, IT \& Social Sciences
Available online at https://sloap.org/journals/index.php/irjmis/
Vol. 6 No. 4, July 2019, pages: 127 134
$\begin{aligned} & \text { ISSN: 2395-7492 } \\ & \text { https://doi.org/10.21744/irjmis.v6n4.666 }\end{aligned}$

\title{
Effect of Service Quality, Company Image, and Customer Satisfaction in Word Of Mouth
}

Komang Melastri ${ }^{a}$

I.G.A.K. Giantari ${ }^{b}$

\section{Article history:}

Received: 18 March 2019

Accepted: 31 May 2019

Published: 05 July 2019

\section{Keywords:}

company image;

customer;

satisfaction;

service quality;

word of mouth;

\begin{abstract}
The sample of this study was 155 respondents, taken using the Random Sampling technique, with the criteria that respondents were attending an English Language Business English program at EF Denpasar, and education at least graduated from high school or equivalent. The results of the study show that (1) Service quality has a positive and significant effect on customer satisfaction. (2) The company's image has a positive and significant effect on customer satisfaction. (3) Service quality has a positive and significant effect on WOM (Word of Mouth), (4) Company image has a positive and not significant effect on WOM and (5) Customer satisfaction has a positive and significant effect on WOM managerial implications and suggestions for increasing EF English First Denpasar WOM, by increasing customer satisfaction and service quality. Customer satisfaction is enhanced by improving the company's image and increasing the professionalism of EF English First Denpasar teachers.
\end{abstract}

2395-7492@ Copyright 2019. The Author. This is an open-access article under the CC BY-SA license (https://creativecommons.org/licenses/by-sa/4.0/) All rights reserved.

\section{Author correspondence:}

Komang Melastri,

Faculty of Economics and Business, Udayana University, Denpasar, Indonesia

Email address: komangmelastri@gmail.com

\section{Introduction}

Kotler \& Keller (2012), describe WOM as a communication process in providing advice and recommendations, both individually and in groups for a product or service that aims to provide information personally. WOM is a communication channel that is often used by companies because it is delivered from consumers by consumers and for consumers, so that consumers or satisfied customers can be a representation of advertising media for the company. In addition, WOM's personal communication channel does not require large costs because, through satisfied customers, references or references to products produced by the company will be easier to spread to other consumers.

Shimp (2010), explains that WOM communication is a marketing medium from consumers to consumers either verbally, in writing, or using electronic media related to the benefits or experience of buying or using a product or

${ }^{a}$ Faculty of Economics and Business, Udayana University, Denpasar, Indonesia

${ }^{\mathrm{b}}$ Faculty of Economics and Business, Udayana University, Denpasar, Indonesia 
service. It also explains that the form of WOM communication is carried out interpersonally with the brand and consumer image as the main resource. Communication conducted by consumers based on a brand image (positive) from the mouth tends to affect the attitude of buying other people, making it easier for business people and marketers to reposition brand images.

Rambe et al., (2017), states that there are several things that affect the occurrence of word of mouth (WOM) by consumers, including service quality, corporate image, and customer satisfaction. Tjiptono \& Chandra (2011), states that the quality of service is the expected level of excellence and control of the level of excellence to meet customer desires. In other words, there are two main factors that affect the quality of service, namely the expected service and perceived service. If the service received or perceived (perceived service) is as expected, then the quality of service services is perceived as good and satisfying.

Rahayu \& Saryanti (2014), state that service quality has a positive effect on customer satisfaction, so if service quality variables are improved then customer satisfaction will increase. In other words, the better the quality of service perceived by consumers, the more satisfied consumers will be. Kwun et al., (2013), stated that service quality has a significant effect on word of mouth (WOM). This means that the better the quality of service perceived by consumers, the more consumers will intend to carry out the positive word of mouth communication, and vice versa if the worse the quality of service perceived by consumers, consumers will tend to do negative word of mouth.

Adbel-Salam et al., (2010), defines a corporate image as a general impression left in the minds of consumers as a result of a collection of feelings, ideas, attitudes, and experiences with companies that are stored in memory. The impression is then transformed into a positive or negative image according to the feelings and experiences of consumers in the company. Both positive and negative images will then be recalled when the name of the company is heard or carried into consumer memory.

Riduan et al., (2015), stated that corporate image has a positive and significant effect on customer satisfaction. Rahayu \& Saryanti (2014), state that corporate image has a positive effect on customer satisfaction, so if the corporate image variable (promotion) is increased then customer satisfaction will increase. Suryaatmaja et al., (2016), states that corporate image has a positive and significant effect on WOM (word of mouth). This means that the higher the company's image, the more word of mouth will be carried out by consumers.

Daryanto \& Setyobudi (2014), state that customer satisfaction is an emotional assessment of consumers after consumers use a product, where the expectations and needs of consumers who use it are met. Kapoor \& Solomon (2011), states that customer satisfaction is an overall feeling of consumers about products or services that have been purchased by consumers. Daryanto \& Setyobudi (2014); Billaiya et al., (2017), state that customer satisfaction is affected by the quality of products or goods given to customers in the process of service delivery, service quality, perception of prices, and situational and personal factors.

Ghalandari et al., (2013); Sari et al., (2018; 2019), stated that consumer satisfaction has a positive effect on WOM (word of mouth). Suryani \& Hendryadi (2015), stated that consumer satisfaction has a significant relationship with WOM (word of mouth) and loyalty. This shows that the level of satisfaction is one of the important things that affect consumer intention to do word of mouth. The more consumers feel satisfied with the product/service of a company, the more positive and more positive word of mouth (WOM) will be. This will certainly be very beneficial for the company.

\section{Literature Review and Hypothesis Development}

\section{Relationship between service quality and customer satisfaction}

Rahayu \& Saryanti (2014) state that service quality has a positive effect on customer satisfaction, so if service quality variables are improved then customer satisfaction will increase. This statement is supported by Rezvani \& Safahani (2016); Li (2013); Jiewanto et al., (2012); Kwun et al., (2013); Kim et al., (2014); Riduan et al., (2015); Retnaningsih (2013); Ghalandari (2013); Purwandari (2015); Suryaatmaja et al., (2016); Setiawan \& Sayuti (2017), and Rambe et al., (2017), which states that service quality has a positive and significant effect on customer satisfaction. H1: Service quality has a positive and significant effect on customer satisfaction.

\section{Relationship between company image and customer satisfaction}

Sallam (2016), states that the corporate image has a positive effect on consumer satisfaction and trust. Rahayu \& Saryanti (2014); Chanana \& Gupta (2016), state that corporate image has a positive effect on customer satisfaction, so 
if the corporate image variable (promotion) is increased then customer satisfaction will increase. This is supported by Riduan et al., (2015); Retnaningsih (2013); Purwandari (2015); Suryaatmaja et al., (2016); Setiawan \& Sayuti (2017); and Rambe et al., (2017), which states that corporate image has a positive and significant effect on customer satisfaction.

H2: Company image has a significant positive effect on customer satisfaction.

Relationship between service quality and WOM (word of mouth)

Kwun et al., (2013); Tripathy (2018), stated that service quality has a significant effect on word of mouth (WOM). Purwandari (2015), also states that there is a positive and significant relationship between service quality and word of mouth (WOM). This statement is supported by Rezvani \& Safahani (2016); Riduan et al., (2015); Suryaatmaja et al., (2016); and Rambe et al., (2017), which states that service quality has a positive and significant effect on word of mouth (WOM). Contrary to the results of research conducted by Jiewanto et al., (2012), which states that service quality does not have a significant effect on word of mouth (WOM). This is supported by Li (2013), which states that perceived service quality does not have a direct impact on WOM, but must first pass customer satisfaction and then be followed by customer loyalty to create WOM.

H3: Service quality has a significant positive effect on WOM (word of mouth).

Relationship between company image and WOM (word of mouth)

Suryaatmaja et al., (2016), states that corporate image has a positive and significant effect on WOM (word of mouth). This is supported by the results of research by Jiewanto et al., (2012); Riduan et al., (2015); Sugianto (2016); and Rambe et al., (2017), which states that corporate image has a positive and significant effect on WOM (word of mouth). The statement contradicts the results of research conducted by Purwandari (2015), which states that a corporate image does not significantly effect WOM (word of mouth).

H4: Company image has a significant positive effect on WOM (word of mouth).

Relationship between consumer satisfaction and WOM (word of mouth)

Ghalandari et al., (2013), stated that consumer satisfaction has a positive effect on WOM (word of mouth). Suryani \& Hendryadi (2015), stated that consumer satisfaction has a significant relationship with WOM (word of mouth) and loyalty. This is supported by the results of the research of Rezvani \& Safahani (2016); Sallam (2016); Kim et al., (2014); Riduan et al., (2015); Purwandari (2015); Suryaatmaja et al., (2016); Kurniawan (2016); Sugianto (2016); and Rambe et al., (2017), which states that consumer satisfaction has a positive and significant effect on WOM (word of mouth). Contrary to the results of research conducted by Jiewanto et al., (2012), which states that there is no significant effect of customer satisfaction on WOM (word of mouth). Supported by the results of research conducted by Li (2013), which states that customer satisfaction does not have a direct effect on WOM, but must be through customer loyalty to form WOM.

H5: Consumer satisfaction has a significant positive effect on WOM (word of mouth).

\section{Materials and Methods}

This study uses explanatory research, which describes a relationship between variables through testing hypotheses. The model used in this study is a model of causality which is a study that aims to determine the causal relationship between exogenous variables and endogenous variables. This research was conducted in Denpasar City. The scope of the research is service quality, corporate image, customer satisfaction, and word of mouth (WOM) at EF English First.

The population in this study were students who were participating in an English language course at EF English First in Denpasar, especially Business English programs, whose numbers could be calculated finite by 185 students. The consideration chosen by the population in the Business English program is because the program is an English language course program for students aged over 18 years (who have graduated from high school/equivalent) who are considered able to understand each item in the research questionnaire.

The sample is part of the population owned by the population. Ferdinand (2014), states that the sample size for testing models using SEM is between 100-200 or depends on the number of parameters used in all latent variables,

Melastri, K., \& Giantari, I. (2019). Effect of service quality, company image, and customer satisfaction in Word Of Mouth. International Research Journal of Management, IT and Social Sciences, 6(4), 127-134. https://doi.org/10.21744/irjmis.v6n4.666 
namely the number of parameters multiplied by 5 to 10 . This study uses 31 indicators so that by using estimates based on the number of parameters obtained a sample size of 100-200 respondents. In this study, a sample of 155 respondents (31 X 5 indicators) was taken.

The sample is probability sampling, which is a technique that provides the same opportunity or opportunity for each element or member of the population to be selected as a sample. The sampling technique used in this study is random sampling. Random sampling is a sampling technique in which all members of the population are assumed to have the same opportunity to be selected as a sample of research, namely students who are taking an English course, especially the Business English program at EF English First, Denpasar City.

This study aims to prove and analyze effect exogenous variables towards endogenous variables. The effect is very complex, where there are latent variables formed by several indicators (observed variable). Based on the hypothesis in this study, the data analysis method used is SEM (Structural Equation Modeling) analysis of the AMOS statistical package.

\section{Results and Discussions}

Statistical test results of processing with the Structural Equation Model (SEM) are carried out through probability (p) and critical ratio $(\mathrm{CR})$ values of each relationship between variables:

Table 1

Regression Weight Full Model

\begin{tabular}{|c|c|c|c|c|c|c|c|}
\hline & & & Estimate & S.E. & C.R. & $\mathrm{P}$ & Information \\
\hline Service Quality & $--->$ & $\begin{array}{l}\text { Consumer } \\
\text { Satisfaction }\end{array}$ & 0,153 & 0,076 & 2,026 & 0,043 & Significant \\
\hline Company Image & $--->$ & $\begin{array}{l}\text { Consumer } \\
\text { Satisfaction }\end{array}$ & 0,200 & 0,073 & 2,752 & 0,006 & Significant \\
\hline Service Quality & $--->$ & WOM & 0,462 & 0,077 & 6,004 & 0,000 & Significant \\
\hline Company Image & $--->$ & WOM & 0,056 & 0,068 & 0,832 & 0,406 & Non Significant \\
\hline $\begin{array}{l}\text { Consumer } \\
\text { Satisfaction }\end{array}$ & $-->$ & WOM & 0,354 & 0,079 & 4,483 & 0,000 & Significant \\
\hline
\end{tabular}

Data Primer, 2019

The probability of service quality is 0.043 which is less than 0.05 so that $\mathrm{p}(0.043)$ off cut off value (0.05), so H0 is rejected. This shows that at the 5 percent significance level, service quality has a significant effect on customer satisfaction.

The probability of a company image is 0.006 which is less than 0.05 so that $\mathrm{p}(0.006)$ is cut off value $(0.05)$, so H0 is rejected. This shows that at the 5 percent significance level, the company's image has a significant effect on customer satisfaction.

The probability of service quality is 0,000 which is less than 0.05 so that $\mathrm{p}(0,000)$ is cut off value $(0.05)$, so H0 is rejected. This shows that at the 5 percent significance level, service quality has a significant effect on word of mouth (WOM).

The probability of a company image is 0.406 which is greater than 0.05 so that $\mathrm{p}(0.406)>$ cut off value $(0.05)$ so that $\mathrm{HO}$ is accepted. This shows that at the 5 percent significance level, the company's image has no significant effect on word of mouth (WOM).

The probability of consumer satisfaction is 0,000 which is less than 0.05 so that $\mathrm{p}(0,000)$ is cut off value $(0.05)$, so $\mathrm{H} 0$ is rejected. This shows that at the 5 percent significance level, consumer satisfaction affects word of mouth (WOM).

\section{The Effect of service quality on customer satisfaction at EF English First Denpasar}

The results of the statistical analysis show that service quality has a positive and significant effect on consumer satisfaction at EF English First Denpasar. The results of data analysis obtained a probability of 0.043 which is smaller than 0.05. This means, the higher the reliability of EF English First Denpasar officers in providing information, launching procedures, solving problems and keeping promises to consumers, it will affect higher customer satisfaction. 
These results are in accordance with the research conducted by Suryani \& Hendryadi (2015), there are dimensions of service quality, namely SPA (Service Portfolio and Assurance) and COM (Reliability of Communication) that have a significant influence on customer satisfaction. Rahayu \& Saryanti (2014), state that service quality has a positive effect on customer satisfaction. So if the quality of service is improved then customer satisfaction will increase. This statement is supported by Rezvani \& Safahani (2016); Li (2013); Jiewanto et al., (2012); Kwun et al., (2013);Kim et al., (2014); Riduan et al., (2015); Retnaningsih (2013); Ghalandari (2013); Purwandari (2015); Suryaatmaja et al., (2016); Setiawan \& Sayuti (2017); and Rambe et al., (2017), which states that service quality has a positive and significant effect on customer satisfaction.

\section{The Effect of company image on consumer satisfaction EF English First Denpasar}

The results of data analysis statistically show that the company's image has a positive and significant effect on consumer satisfaction at EF English First Denpasar. The results of data analysis obtain a probability of 0.006 which is smaller than 0.05. This means, the higher the level of professionalism of teachers at EF English First Denpasar, the higher the customer satisfaction will be. This result according to the research conducted by Sallam (2016), states that the corporate image has a positive influence on consumer satisfaction and trust. Rahayu \& Saryanti (2014), state that corporate image has a positive effect on customer satisfaction, so if the corporate image variable (promotion) is increased then customer satisfaction will increase. This is supported by Riduan et al., (2015); Retnaningsih (2013); Purwandari (2015); Suryaatmaja et al., (2016); Setiawan \& Sayuti (2017); and Rambe et al., (2017), which states that corporate image has a positive and significant effect on customer satisfaction.

\section{The Effect of quality of service on word of mouth (WOM) EF English First Denpasar}

The results of statistical data analysis show that service quality has a positive and significant effect on word of mouth (WOM) EF English First Denpasar. The results of data analysis obtain a probability of 0,000 which is smaller than 0.05. This means that the higher the level of reliability of EF English First Denpasar officers in providing information, launching procedures, solving problems and keeping promises to consumers, it will affect the higher level of word of mouth (WOM) by recommending to others. This result is consistent with the research conducted by Kwun et al., (2013), stated that service quality has a significant effect on word of mouth (WOM). Purwandari (2015), also states that there is a positive and significant relationship between service quality and word of mouth (WOM). This statement is supported by Rezvani \& Safahani (2016); Riduan et al., (2015); Suryaatmaja et al., (2016); and Rambe et al., (2017), which states that service quality has a positive and significant effect on word of mouth (WOM).

\section{The Effect of company image on word of mouth (WOM) EF English First Denpasar}

The results of statistical data analysis show that the company's image has a positive and not significant effect on word of mouth (WOM) EF English First Denpasar. The results of data analysis obtain a probability of 0.406 which is greater than 0.05. This means that the higher the level of professionalism of teachers at EF English First Denpasar, it will not significantly affect the level of higher customer satisfaction. This result is consistent with the research conducted by Purwandari (2015), which states that the corporate image has no significant effect on WOM (word of mouth). The statement contradicts the results of a study conducted by Suryaatmaja et al., (2016), states that corporate image has a positive and significant effect on WOM (word of mouth). This is supported by the results of research by Jiewanto et al., (2012); Riduan et al., (2015); Sugianto (2016); and Rambe et al., (2017), which states that corporate image has a positive and significant effect on WOM (word of mouth).

\section{The Effect of consumer satisfaction on word of mouth (WOM) EF English First Denpasar}

The results of statistical data analysis show that consumer satisfaction has a positive and significant effect on word of mouth (WOM) EF English First Denpasar. The results of data analysis obtain a probability of 0,000 which is smaller than 0.05. This means that the higher the level of benefit conformity with the expectations obtained by EF English First Denpasar consumers, the higher the level of word of mouth (WOM) by recommending it to others. This result is consistent with the research conducted by Ghalandari et al., (2013), stated that consumer satisfaction has a positive influence on WOM (word of mouth). Suryani \& Hendryadi (2015), stated that consumer satisfaction has a significant relationship with WOM (word of mouth) and loyalty. This is supported by the results of the research of Rezvani \&

Melastri, K., \& Giantari, I. (2019). Effect of service quality, company image, and customer satisfaction in Word Of Mouth. International Research Journal of Management, IT and Social Sciences, 6(4), 127-134. https://doi.org/10.21744/irjmis.v6n4.666 
Safahani (2016); Sallam (2016); Kim et al., (2014); Riduan et al., (2015); Purwandari (2015); Suryaatmaja et al., (2016); Kurniawan (2016); Sugianto (2016); and Rambe et al., (2017), which states that consumer satisfaction has a positive and significant effect on WOM (word of mouth).

\section{Conclusion}

Word of mouth (WOM) is obtained through customer satisfaction so that EF English First Denpasar can increase consumer satisfaction by increasing benefit suitability with expectations obtained by consumers. Increasing the suitability of benefits in hopes of increasing EF English First Denpasar's more word of mouth (WOM) high, thus more consumers will buy EF English First Denpasar to others. The company's image shows a positive and significant impact on customer satisfaction, but it is not significant for word of mouth (WOM). Successfully, consumers issue EF English First Denpasar not because of their good image because of the level of satisfaction that consumers get. Service quality shows a positive and significant influence on WOM. Related, by increasing promoting EF English First Denpasar officers in providing information, launching procedures, resolving problems and keeping promises to consumers, more and more consumers get EF English First Denpasar to others.

\section{Research Limitations}

This research only applies to EF English First Denpasar, not valid at other English language training institutions. This research is only conducted at certain time points (cross sections), while the environment can change dynamically at any time, so this research is important to do in the future.

\section{Suggestion}

To improve WOM, it is expected that EF English First Denpasar will increase customer satisfaction and service quality. Customer satisfaction increases by improving the company's image and increasing the professionalism of teachers at EF English First Denpasar. Subsequent research was approved to divide respondents into more balanced, from the number of sexes, monthly income, so that the results of the study could be better. Subsequent research can add constructs besides service quality, and company image to be able to facilitate further customer satisfaction and WOM.

\section{Conflict of interest statement and funding sources}

The authors declared that they have no competing interest.

\section{Statement of authorship}

The authors have a responsibility for the conception and design of the study. The authors have approved the final article.

\section{Acknowledgments}

The authors would like to thank the Editor of IRJMIS for their valuable time, support, and advice in completing the current study. 


\section{References}

Adbel-Salam, K. A., \& Mahmoud, S. M. (1995). Stimulating effects of low levels of 60 Co gamma ray on the silkworm, Bombyx mori (L.). Anzeiger für Schädlingskunde, Pflanzenschutz, Umweltschutz, 68(7), 147-150.

Billaiya, R., Malaiya, S., \& Parihar, K. S. (2017). Impact of socio economic trends on students in quality education system. International Journal of Social Sciences and Humanities, 1(1), 16-20. https://doi.org/10.29332/ijssh.v1n1.10

Chanana, M., \& Gupta, K. (2016). Quality of work life and its impact on job performance: a study of S.B.I \& HDFC banking professionals. International Research Journal of Management, IT and Social Sciences, 3(5), 16-24.

Daryanto \& Setyobudi, I. (2014). Konsumen dan Pelayanan Prima. Yogyakarta: Gava Media.

Ferdinand, A. (2014). Pedoman Penelitian Untuk Penulisan Skripsi Tesis dan Disertasi Ilmu Manajemen: Metode Penelitian Manajemen: Semarang: Badan Penerbit Universitas Diponegoro.

Ghalandari, K. (2013). The effect of service quality on customer perceived value and customer satisfaction as factors influencing creation of word of mouth communications in Iran. Journal of Basic and Applied Scientific Research, 3(4), 305-312.

Jiewanto, A., Laurens, C., \& Nelloh, L. (2012). Influence of service quality, university image, and student satisfaction toward WOM intention: A case study on Universitas Pelita Harapan Surabaya. Procedia-Social and Behavioral Sciences, 40, 16-23. https://doi.org/10.1016/j.sbspro.2012.03.155

Kapoor, C., \& Solomon, N. (2011). Understanding and managing generational differences in the workplace. Worldwide Hospitality and Tourism Themes, 3(4), 308-318. https://doi.org/10.1108/17554211111162435

Kim, M. K., Lee, D. H., Schoenstedt, L., Lee, S. B., \& Kim, S. (2014). Effects of service quality in motor boat racing: relationships among perceived value, customer satisfaction, and word-of-mouth. International Journal of Sports Science, 4(2), 39-46.

Kotler, P., \& Armstrong, G. (2012). Principles of Marketing 14th Edition New Jersey: Pearson Prentice Inc.

Kurniawan, D. A. (2016). Pengaruh Persepsi Harga, Kualitas Pelayanan dan Citra Terhadap Niat Konsumen untuk Word of Mouth dengan Kepuasan sebagai Variabel Mediasi (Survei pada BPJS di Kabupaten Ponorogo). Al Tijarah, 2(1), 94-118.

Kwun, D. J. W., Ellyn, E., \& Choi, Y. (2013). Campus foodservice attributes and their effects on customer satisfaction, image, and word-of-mouth. Journal of foodservice business research, 16(3), 276-297. https://doi.org/10.1080/15378020.2013.810534

Li, S. C. (2013). Explore the Relationships among Service Quality, Customer Loyalty and Word-Of-Mouth for Private Higher Education in Taiwan. Asia Pacific Management Review.

Purwandari, S. (2015). Pengaruh Kualitas Layanan, Citra, Lokasi Dan Kualitas Pengajar Terhadap Word Of Mouth Dengan Kepuasan Sebagai Pemediasi (Studi Pada Politeknik Indonusa Surakarta). Jurnal Sainstech Politeknik Indonusa Surakarta, 2(4).

Rahayu, B. S., \& Saryanti, E. (2014). Pengaruh Kualitas Pelayanan, Hubungan Pelanggan dan Citra Perusahaan terhadap Loyalitas Melalui Kepuasan Nasabah. ADVANCE, 1(2).

Rambe, P., \& Mpiti, N. (2017). The Influence of private and public finance, organisational and environmental variables on the performance of Beauty Salons in the Free State, South Africa: A theoretical perspective.

Retnaningsih, W. (2000). Effect of Image Quality Service and Schools Parents of Satisfaction in Surabaya. organization, $347,4$.

Rezvani, M., \& Safahani, N. (2016). The effect of site quality on electronic word of mouth marketing through mediating variable of customer satisfaction (case study: Tiwall culture and art social network online shop). International Business Management, 10(4), 592-598.

Riduan, S. N., Zhang, Y., \& Ying, J. Y. (2009). Conversion of carbon dioxide into methanol with silanes over Nheterocyclic carbene catalysts. Angewandte Chemie International Edition, 48(18), 3322-3325.

Sallam, M. A. (2016). An Investigation of Corporate Image Effect on WOM: The Role of Customer Satisfaction and Trust. International Journal of Business Administration, 7(3), 27-35.

Sari, D. M. F. P., \& Pradhana, I. P. D. (2018). Brand name, image, word of mouth towards buying habits and customer loyalty online shop. International Research Journal of Management, IT and Social Sciences, 5(2), 216-226.

Sari, D. M. F. P., \& Yulianti, N. M. D. R. (2019). Celebrity endorsement, electronic word of mouth and trust brand on buying habits. International Journal of Social Sciences and Humanities, 3(1), 82-90. https://doi.org/10.29332/ijssh.v3n1.261

Melastri, K., \& Giantari, I. (2019). Effect of service quality, company image, and customer satisfaction in Word Of Mouth. International Research Journal of Management, IT and Social Sciences, 6(4), 127-134. https://doi.org/10.21744/irjmis.v6n4.666 
Setiawan, H., \& Sayuti, A. J. (2017). Effects of service quality, customer trust and corporate image on customer satisfaction and loyalty: an assessment of travel agencies customer in South Sumatra Indonesia. IOSR Journal of Business and Management, 19(5), 31-40.

Shimp, T. A. (2010). Advertising Promotion and Other Aspects of Interated Marketing Communication 8thEdition. Canada: Nelson Education, Ltd.

Sugianto, N., Muhammad, F., \& Wiwit, S. (2016). Local geology condition of bengkulu city based on seismic vulnerability index (Kg). ARPN Journal of Engineering and Applied Sciences, 11(7), 4797-4803.

Suryaatmaja, A. N., Suprapti, N. W. S., \& Yasa, N. N. K. (2016). Pengaruh kualitas pelayanan dan citra terhadap kepuasan dan word of mouth nasabah. E-Jurnal Ekonomi dan Bisnis Universitas Udayana.

Suryani, S., \& Hendryadi, H. (2015). A developing model of relationship among service quality, consumer satisfaction, loyalty and word of mouth in Islamic Banking. Al-Iqtishad: Jurnal Ilmu Ekonomi Syariah, 7(1), 45-58.

Tjiptono, F., \& Gregorius, C. (2011). Service Quality \& Satisfaction, Yogyakarta: Penerbit ANDI. Edisi III.

Tripathy, M. (2018). Building quality teamwork to achieve excellence in business organizations. International Research Journal of Management, IT and Social Sciences, 5(3), 1-7. 